\title{
Effects of restricted nursing on milk production and collection, kid growth and plasma prolactin and growth hormone concentrations in dairy goats
}

\author{
H. Hernández ${ }^{1,2}$, J. A. Delgadillo ${ }^{2}$, J. A. Flores ${ }^{2}$, A. D. Rodríguez ${ }^{1}$, N. Serafín ${ }^{1}$, G. Kann ${ }^{3}$, \\ P. G. Marnet ${ }^{4}$ and P. Poindron ${ }^{1 \dagger}$
}

\begin{abstract}
${ }^{1}$ Instituto de Neurobiología, UNAM, Km 15 Carretera Querétaro-San Luís Potosí, Campus Juriquilla, Querétaro 76230, Querétaro, México; ${ }^{2}$ Centro de Investigación en Reproducción Caprina (CIRCA), Departamento de Ciencias Médico-Veterinarias, Universidad Autónoma Agraria Antonio Narro, Carretera a Santa Fe y Periférico, Torreón, 27000 Coahuila, México; ${ }^{3}$ Unité de Recherches sur l'Endocrinologie du Placenta et de la Périnatalité, Laboratoire de Biologie Cellulaire et Moléculaire, INRA, 78352 Jouy en Josas Cedex, France; ${ }^{4}$ INRA/ENSAR Laboratoire Associé de Recherche sur la Traite, INRA, 65, rue de Saint-Brieuc, 35042 Rennes Cedex, France
\end{abstract}

(Received 25 July 2006; Accepted 9 November 2006)

The milk production of dairy goats under various regimes of mother-young contact from day 4 post partum were studied during the first 2 months of lactation, together with the prolactin (PRL) and growth hormone (GH) responses to udder stimulation. In the control group, 13 goats and their kids were left in permanent contact and did not undergo milking. In two additional groups, goats were machine milked once a day in the morning (at $0800 \mathrm{~h}$ ) and kids were allowed 10 hours (from 1000 to $2000 \mathrm{~h} ; 10 \mathrm{H}$ group, $n=11$ ) or $5 \mathrm{~h}$ (from 1000 to $2000 \mathrm{~h} ; 5 \mathrm{H}$ group, $n=11$ ) of mother-young interaction per day. In the last group (MO, $n=10)$, mothers were permanently separated from their kids on day 4 post partum and milked once a day. Milk production during a 24-h period at 37 days post partum performed by controlled nursing and weighing of the kids (groups with kids) or by two machine milking $12 \mathrm{~h}$ apart (milking only group) revealed a higher production in the three groups with some mother-young contact than in the MO group. Total milk collected by milking over the 2 months of the study did not differ between the three groups that underwent milking. Kid weights at 2 months were 3.4 to $4.8 \mathrm{~kg}$. lighter in the groups that underwent milking than in the control group. Hormonal profiles were significantly affected by restricted mother-young contact, with highest pre-stimulation concentrations of PRL and GH in the $5 \mathrm{H}$ group. Restricting mother-young contact from the first week postpartum can permit an early collection of milk without major effects on kid growth, when compared with one daily milking in goats totally separated from their young.

Keywords: goats, hormones, maternal behaviour, milk production, suckling.

\section{Introduction}

Under temperate climatic conditions, goats are generally used for milk production and kids represent only a secondary product (Knights and Garcia, 1997). Young are removed from their mother soon after birth and artificially reared, allowing the farmer to process all the milk produced by the dam. On the other hand, in subtropical and tropical developing countries, kids are reared by their dam and meat production is generally the main objective (Food and Agriculture Organisation, 1982; Ferrando and Boza, 1990; Knights and Garcia, 1997). Therefore, in these countries,

\footnotetext{
${ }^{\dagger}$ Corresponding author: Present address: UMR 6175, Physiologie de la Reproduction et des Comportements, INRA, 37380 Nouzilly, France. E-mail: poindron@ tours.inra.fr
}

most breeders start milking when the kids have grown enough to be sold for slaughter, at between 1 and 2 months of age. Nevertheless, some producers also practice early weaning of the kids, even though the mothers are milked only once a day. This implies that the kids are reared artificially and therefore there is an extra cost due to the purchase of the milk substitute and to the work necessary for feeding the kids, as well as possible welfare problems due to the early and complete rupture of the mother-young bond.

In dairy animals, there are indications that the presence of a mother-young relationship is beneficial for milk production. Thus, in some breeds of cattle, the presence of the young is necessary for lactation to be maintained (Le Neindre, 1984) or for milk ejection to occur (Alvarez et al., 1980). Also, the presence of the young can modulate 
the release of galactopoïetic hormones following udder stimulation. The release of PRL and GH was higher in cows milked three times a day and also sucked three times a day, than in cows only milked six times a day (Bar-Peled et al., 1995). In addition, in this same study, milk production was found to be higher in milked and sucked cows than in milked-only cows. A positive effect of the presence of the calf on PRL release has also been reported in nursing cows by Perez et al. (1985), although not by others (Akers and Lefcourt, 1984). In small dairy ruminants, maintaining some mother-young interaction during lactation also appears to have beneficial effects on milk production: when milking is combined with restricted mother-young contact in goats and sheep, it does not significantly reduce the quantity of milk obtained by milking (Folman et al., 1966; Morag et al., 1970; Hadjipanayiotou, 1985; Papachirtoforou, 1990; Peris et al., 1997), and can even lead to a higher milk collection (Hadjipanayiotou and Louca, 1976). However, to our knowledge the possible beneficial consequences of maintaining some mother-young contact on milk production in goats, when the udder is emptied by milking only once daily, have not been investigated in previous research. The effects of such a management procedure on PRL and GH release also remain unknown, although it has been reported in rodents that the interval between nursing episodes can influence the hormonal response in the mother (Grosvenor et al., 1979).

In Mexico, as in many subtropical and tropical developing countries, collected milk represents an important source of food for the community and may be in some cases the main source of income for the producers (Hoyos et al., 1991). However, this is also often associated with kid meat production, and the first 30 to 60 days of lactation are generally not taken advantage of for milk collection, because this period is entirely dedicated to the consumption of milk by the kids (Cepeda, 1993). Whether kids could readily adapt to restricted periods of suckling from an earlier stage in life is not known. This may well be the case, given their early hiding behaviour and the initially low suckling rhythms associated with it (Rudge, 1970; Coblentz, 1974; McDougall, 1975; Lickliter, 1984). However, such an adaptation may be more stressful after the 1st week of life, since these suckling frequencies are much higher from the 2 nd week post partum onwards (Lévy and Alexandre, 1985; Delgadillo et al., 1997). Therefore, imposing a limited time of daily mother-kid interaction with one daily milking may allow some increase of milk collected in traditional management systems found in Mexico and other developing countries. Nevertheless, it is also necessary to assess to which extent the mother and the young can adapt to daily-restricted mother-young contact.

Therefore, an experiment was carried out in dairy goats to investigate to what extent a restriction of daily mother-young interactions starting on day 4 post partum, could be compatible with an adequate development of the kids and one daily collection of milk. To this end, growth of the kids and milk collected by one daily machine-milking were compared over the first 2 months of lactation in goats and their kids allowed $10 \mathrm{~h}, 5 \mathrm{~h}$ or no mother-young contact, while a group of mothers and kids allowed permanent interactions and no milking was used as positive control. Also, given the results reported in cattle, we investigated if the restriction or suppression of mother-young interactions could affect the PRL and $\mathrm{GH}$ response to udder stimulation in goats placed under these experimental conditions.

\section{Material and methods}

\section{Location}

The study was conducted during the months of January to April at the Facultad de Estudios Superiores (FESC-UNAM) of Cuautitlán Izcalli in the State of Mexico, Mexico (latitude: $19^{\circ} \mathrm{N} ; 2240 \mathrm{~m}$ above sea level; average temperature during the study: from 12 to $16^{\circ} \mathrm{C}$ ).

Animals, management conditions and experimental design Animals were 45 Alpine goats maintained under intensive management $\left(5 \mathrm{~m}^{2}\right.$ per dam) in four corrals (one for each group) provided with shade. They were fed twice daily with lucerne hay and commercial concentrate (Generaleche, Purina Mexico, $140 \mathrm{~g} / \mathrm{kg}$ of crude protein), according to their physiological requirements (National Research Council, 1981), and had free access to water and mineral blocks. At parturition, kids were weighed and identified by ear tagging, and the mothers were allocated to one of the following four groups.

Control group (C). Three primiparous and 10 multiparous goats (prolificacy: $1.7 \pm 0.2$ ), left in permanent contact with their kids. Five goats reared one kid, seven reared twins and one had triplets.

10 hours group (10H). Three primiparous and eight multiparous goats (prolificacy: $1.6 \pm 0.2$ ), left in daily contact with their kids from $1000 \mathrm{~h}$ to $2000 \mathrm{~h}$ and machine-milked once daily in the morning at $0800 \mathrm{~h}$. Five goats reared one kid, five reared twins and one reared triplets.

5 hours group (5H). Three primiparous and eight multiparous goats (prolificacy: $1.7 \pm 0.2$ ), left in daily contact with their kids from $1500 \mathrm{~h}$ to $2000 \mathrm{~h}$, and milked once daily in the morning at $0800 \mathrm{~h}$. Five goats reared one kid, four reared twins and two reared triplets.

Milking only group (MO). Three primiparous and seven multiparous goats (prolificacy $1.7 \pm 0.2$ ) permanently separated from their kids on day 4 post partum and milked once daily in the morning at $0800 \mathrm{~h}$. Four goats reared one kid, five reared twins and one reared triplets.

Taking into account all mothers, there was no effect of parity of goats on the prolificacy. The treatments started on day 4 post partum and the study ended on day 60 of 
lactation. On day 4, kids from the MO group were totally separated from their dam and kept in a separate pen, in which they were bottle-fed ad libitum twice daily with the milk obtained from the mothers of this same group. In the two groups with restricted contact, kids were progressively accustomed to daily separation, in order to reach the scheduled restriction on day 7 , when the measurements were initiated. In addition to the access to the feed given to the dams in the control group, in the three other groups the kids also had free access to lucerne hay and concentrate during the whole study in the daily periods when they were separated from their mothers. The machine milking routine and the milker were the same during the whole study in all groups. The milking machine was an Alfa-Laval with a HP 102 pulsator. The number of pulsations was 85 per min and the vacuum was set at $42 \mathrm{kPa}$.

\section{Production parameters}

Total collected milk. In the three groups in which milking was performed, we measured the total quantity of milk obtained $(\mathrm{kg})$ from day 7 to day 60 of the study by summing up the daily quantity obtained during machine milking. Measures were taken from day 7 post partum up to the end of the study at 60 days of lactation.

Total milk production in a 24-h period. This was estimated at day 37 of lactation over a period of $24 \mathrm{~h}$ by the method of differential body weight of the kids before and after sucking (Ricordeau et al., 1960) in the $\mathrm{C}, 10 \mathrm{H}$ and $5 \mathrm{H}$ groups. In the MO group these values were obtained by two machine-milkings at 12-h intervals. The details of the procedure are shown in Table 1. In all groups, the udder was first emptied in the morning before initiating the measurements. In all cases, hand milking was performed to extract any residual milk after each suckling or milking and this weight was added to that of the corresponding measurement. Total milk production for the 24-h period was calculated by summing up the quantities obtained during the measurements from $1030 \mathrm{~h}$ (nursing groups) or $1930 \mathrm{~h}$ (MO group) and the following ones, up to the next morning.

Kids body weight. In all groups, kids were weighed weekly and daily growth rates were calculated. Weighing was performed in the morning, before the kids of the restrained group were reunited with their mothers and before feeding of the MO kids.

Hormonal response to udder stimulation at 35 days of lactation

The PRL and GH responses to udder stimulation were estimated on five (three with single, $S$, and two with twins, $T$ ), 6 (1S and 5T), 4 (2S and 2T), and 5 (1 S and $4 \mathrm{~T}$ ) multiparous females from the $\mathrm{C}, 10 \mathrm{H}, 5 \mathrm{H}$ and $\mathrm{MO}$ groups, respectively. On day 35 of lactation, serial blood samplings were carried out in these females at the time of controlled udder stimulation. Nursing dams were sampled in an individual

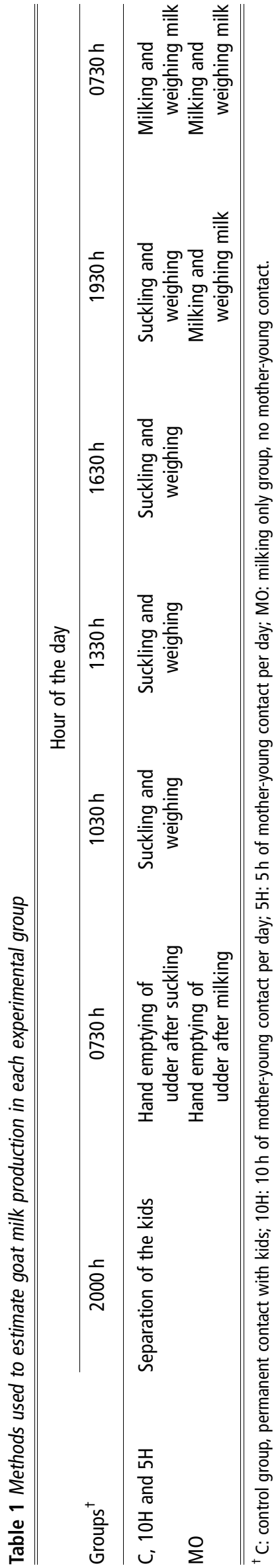


pen $(2 \times 2 \mathrm{~m})$, located inside the pen in which the goat and her kid(s) were normally kept during the study; MO females were sampled in the milking parlour. Ninety minutes before the onset of the samplings, a heparinised catheter was inserted into the jugular vein under local anaesthesia. Ten samples were taken at -1.0 , $-0.5,+0.5,+1.0,+1.5,+2,+3,+4,+6,+10$ and $+15 \mathrm{~min}$ relative to the onset of udder stimulation. Stimulation occurred during $4 \mathrm{~min}$ in the presence of the $\mathrm{kid}(\mathrm{s})$ with free suckling $(\mathrm{C}, 10 \mathrm{H}$ and $5 \mathrm{H}$ groups), or during the 3 min of milking (MO group). In the case of mothers with twins, both kids were used for stimulation of the udder. All blood samplings were carried out in the morning, starting between 0900 and $1100 \mathrm{~h}$. In all cases, the kids were removed from their mother at $2000 \mathrm{~h}$ on the previous night. At the time of sampling, previous to the udder stimulation, the kids were brought to a holding pen, $2 \mathrm{~m}$ away from the dams, and the goats were able to see and hear their young. Each blood sample was collected in a different syringe, after which the blood was put in a heparinised vacutainer tube, maintained on ice after the sampling. At the end of each sampling period, the tubes were centrifuged at 4000 r.p.m. at $4^{\circ} \mathrm{C}$ and the plasma was stored at $-20^{\circ} \mathrm{C}$ until hormonal assay.

\section{Hormonal assays}

Plasma PRL and GH concentrations were determined by radio-immunoassay in accordance to the methods described by Kann (1971) and Lacroix et al. (1996), respectively. The detection threshold for PRL was $1.24 \mathrm{ng} /$ $\mathrm{ml}$ and the inter- and intra-assay coefficients of variation were $4.5 \%$ and $12.6 \%$ respectively. For $\mathrm{GH}$, these coefficients were $11 \%$ and $5.8 \%$ respectively, with a sensitivity of $0.62 \mathrm{ng} / \mathrm{ml}$.

\section{Statistical analysis}

Global effects of group and time on hormonal concentrations (PRL and $\mathrm{GH}$ ) were analysed through two-way ANOVA for repeated measures (nursing regimen as between-factor and time of sampling as within-factor). Comparisons of basal and maximal concentrations, amplitude of the response and time of maximal response were carried out using non-parametric tests (Kruskall-Wallis,
Mann-Whitney and Wilcoxon tests) because of the relatively small sampling size. The total of milk collected during the study and milk production at 37 day postpartum were analysed by one-way ANOVA for group effect and in case of a significant effect of treatment, comparisons of means were performed using the post hoc LSD test. Changes in live weight of kids were analysed by two-way ANOVA for repeated measures (treatment as between-factor and time of experiment as within-factor; Systat 7.0, Statistical Packages for the Social Sciences, 2000). In addition, post hoc LSD tests were carried out whenever significant differences were found. Results are expressed as mean \pm standard error.

\section{Results}

Total amount of milk collected through milking

No significant differences were found between the three groups that underwent machine milking in the total quantity of milk collected per goat during the whole study (from day 7 to day 60 post partum; $P=0.61$; Table 2).

Daily milk production at 37 days post partum

The milk production on day 37 post partum was significantly lower in the MO group compared with that in the $\mathrm{C}$, $10 \mathrm{H}$ and $5 \mathrm{H}$ groups (Table 2; $P<0.05$ ).

Weaning weights and daily growth rate of the kids (Table 2)

Birth weight of the kids did not differ between groups $(P=0.77)$. In addition to an obvious effect of time, the ANOVA revealed a significant effect of treatment $(P<0.01)$, as well as an interaction between treatment and time $(P<0.01)$ on the increase of weight of the kids during the study. The post hoc analysis showed that the weaning weights in the $\mathrm{C}$ group were higher than in the $10 \mathrm{H}, 5 \mathrm{H}$ or MO groups ( $P \leq 0.03$ in all cases; LSD test). With respect to daily weight gains, the results differed between groups in a similar way: the daily weight gains in the $C$ group were higher than in the three other groups $(P \leq 0.01$ in all cases; LSD test), while these three latter ones did not differ significantly.

Table 2 Effects of various degrees of daily mother-young contact during the first 2 months of lactation on kid growth and doe milk production (means \pm s.e.)

\begin{tabular}{|c|c|c|c|c|}
\hline & $\begin{array}{l}\text { Control } \\
\text { group } \\
(n=22)\end{array}$ & $\begin{array}{c}10 \mathrm{~h} \text { contact } \\
\text { group } \\
(\mathrm{n}=18)\end{array}$ & $\begin{array}{c}5 \mathrm{~h} \text { contact } \\
\text { group } \\
(\mathrm{n}=19)\end{array}$ & $\begin{array}{l}\text { Milking only } \\
\text { group } \\
(n=17)\end{array}$ \\
\hline Birth weight of kids $(\mathrm{kg})$ & $3.89 \pm 0.19$ & $3.98 \pm 0.16$ & $3.88 \pm 0.27$ & $3.63 \pm 0.32$ \\
\hline Weight of kids at 2 months of age $(\mathrm{kg})$ & $16.6^{\mathrm{a}} \pm 0.7$ & $11.8^{\mathrm{b}} \pm 0.7$ & $12.2^{\mathrm{b}} \pm 0.7$ & $13.2^{\mathrm{b}} \pm 0.7$ \\
\hline Daily growth rate $(g)$ & $209^{a} \pm 13$ & $140^{b} \pm 11$ & $148^{b} \pm 9$ & $170^{b} \pm 5$ \\
\hline Milk production in a $24-\mathrm{h}$ period at day 37 post partum $(\mathrm{kg})$ & $3.1^{\mathrm{b}} \pm 0.3$ & $2.9^{b} \pm 0.2$ & $2.7^{b} \pm 0.3$ & $1.8^{\mathrm{a}} \pm 0.3$ \\
\hline Total weight of milk collected from day 7 to day 60 post partum (kg per goat) & & $75.5^{a} \pm 5.1$ & $75.5^{a} \pm 11$ & $89.2^{\mathrm{a}} \pm 15.5$ \\
\hline
\end{tabular}

${ }_{\mathrm{a}, \mathrm{b}}$ Different superscripts within a row indicate significant differences between treatments $(P<0.05)$. 
Hormonal response to udder stimulation at 37 days of lactation

The hormonal response of PRL and GH to udder stimulation in the four groups is summarised in Figures 1 and 2 and in Table 3. The basal concentrations (mean of the two pre-stimulation values) of PRL were significantly different between groups (C: $31.3 \pm 3.4 \mathrm{ng} / \mathrm{ml} ; 10 \mathrm{H}$ : $99.6 \pm 34.8 \mathrm{ng} / \mathrm{ml} ; 5 \mathrm{H}: 242.0 \pm 78.2 \mathrm{ng} / \mathrm{ml} ; \mathrm{MO}: 40.5 \pm$ $6.7 \mathrm{ng} / \mathrm{ml} ; P=0.02)$. In the $5 \mathrm{H}$ group, these concentrations were significantly higher than in the $\mathrm{C}$ or $\mathrm{MO}$ groups $(P<0.05)$, while the difference did not reach significance between $5 \mathrm{H}$ and $10 \mathrm{H}$ groups $(P=0.14)$ or between $\mathrm{C}$ and MO groups $(P=0.11)$. In all groups, the maximum concentrations obtained following udder stimulation were higher than the pre-stimulation concentrations (Table 3) and the differences were significant in all groups except the $5 \mathrm{H}$ group $(P=0.14)$. Maximum concentrations were reached at times ranging from $3.3 \pm 2.3 \mathrm{~min}$ in the $5 \mathrm{H}$ group to $9.0 \pm 1.9 \mathrm{~min}$ in the $\mathrm{MO}$ group, which did not differ significantly $(P=0.18)$ between groups. Also, no significant differences were found between groups in the amplitude of the response (difference between the maximum value and the pre-stimulation value; $P=0.94$ ). When considering the evolution of the concentrations of PRL during sampling, the ANOVA revealed a significant effect of group $(P=0.04)$ and an interaction group $\times$ time $(P<0.01)$.

Concerning $\mathrm{GH}$, there was a significant difference between groups in the concentrations found before stimulation ( $P=0.04$; Table 3$)$. The concentrations found in the control group $(3.7 \pm 0.5 \mathrm{ng} / \mathrm{ml})$ were significantly lower than in any other group $(P<0.05)$, while the three other groups did not differ one from another $(10 \mathrm{H}: 9.1 \pm 2.5 \mathrm{ng} /$ $\mathrm{ml} ; \quad 5 \mathrm{H}: \quad 11.3 \pm 3.0 \mathrm{ng} / \mathrm{ml} ; \quad \mathrm{MO}: \quad 10.0 \pm 2.1 \mathrm{ng} / \mathrm{ml}$; $P>0.40$ ). Maximum concentrations were reached between $3.7 \pm 1.9 \mathrm{~min}$ after beginning of stimulation (C group) and $9.8 \pm 2.4 \mathrm{~min}$ (MO group), and no differences were found between groups for this variable. Maximum concentrations were higher than basal prestimulation concentrations in all groups (Table 3), although the difference did not reach significance in the $5 \mathrm{H}$ group, despite the fact that it was highest in this group $(P=0.07)$. Also, differences between groups were found in the amplitude of the response. This amplitude was significantly lower in the $C$ group $(2.2 \pm 0.6 \mathrm{ng} / \mathrm{ml})$ than in the $10 \mathrm{H}$ and $5 \mathrm{H}$ groups $(10.7 \pm 4.1 \mathrm{ng} / \mathrm{ml}$ and $23.6 \pm 10.6 \mathrm{ng} / \mathrm{ml}$ respectively, $P<0.05)$. The $5 \mathrm{H}$ group also tended to differ from the MO group, although the difference did not reach significance $(7.2 \pm 3.0 \mathrm{ng} / \mathrm{ml}$, $P=0.09$ ). These differences were also reflected in the results of the ANOVA, which showed that $\mathrm{GH}$ release over time tended to be affected by the nursing mode $(P=0.07)$ and by time of sampling $(P=0.06)$, although no significant interaction was found between these two factors.

\section{Discussion}

The results of the present study indicate that the manipulation of the daily mother-young contact duration between dairy goats and their kids has significant repercussions, both for the mothers and the kids.

\section{Milk production}

In dams, restricting nursing allowed milk to be collected in early lactation, and there were no differences between 10 and $5 \mathrm{~h}$ of daily contact with their kids. In contrast, in a traditional management, milking would have started only at 30 to 45 days post partum, after taking the kids away from their dam. Also, even though the quantity of milk collected was $15 \%$ lower in the $10 \mathrm{H}$ and $5 \mathrm{H}$ contact groups than in the MO group, this difference was not significant. While this may have been partly due to the high withingroup variation observed for this variable, it is also certainly related to the fact that the total $24 \mathrm{~h}$ production of milk on day 37 of lactation was significantly higher in the three groups in which the goats had some degree of contact with their young. Indeed, milk production per $24 \mathrm{~h}$ was about $60 \%$ higher at 37 days in the three groups with some mother-young contact than in the MO group. Milk

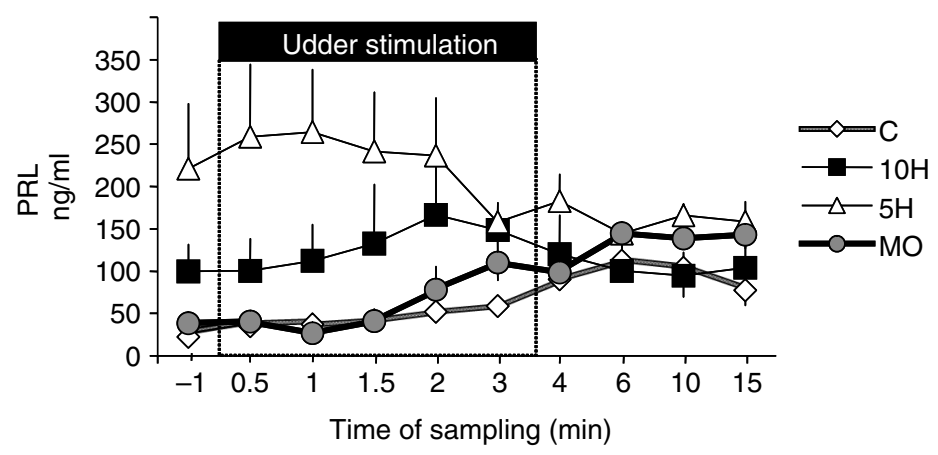

Figure 1 Plasma prolactin concentrations (PRL, mean \pm s.e.) released in response to udder stimulation by 4 min of suckling (C, $10 \mathrm{H}$ and $5 \mathrm{H}$ groups) or $3 \mathrm{~min}$ of machine milking ( $\mathrm{MO}$ group) in goats submitted to different durations of mother-young interaction ( $\mathrm{C}=$ free mother-kid interaction; $10 \mathrm{H}=10 \mathrm{~h}$ of mother-kid interaction per day and one machine milking; $5 \mathrm{H}=5 \mathrm{~h}$ of mother-kid interaction per day and one machine milking; $\mathrm{MO}=$ no mother-kid interaction and only one machine milking per day). Two-way ANOVA showed a significant effect of the group $(P=0.04)$ and a significant interaction between the time of sampling and group $(P=0.01)$. 


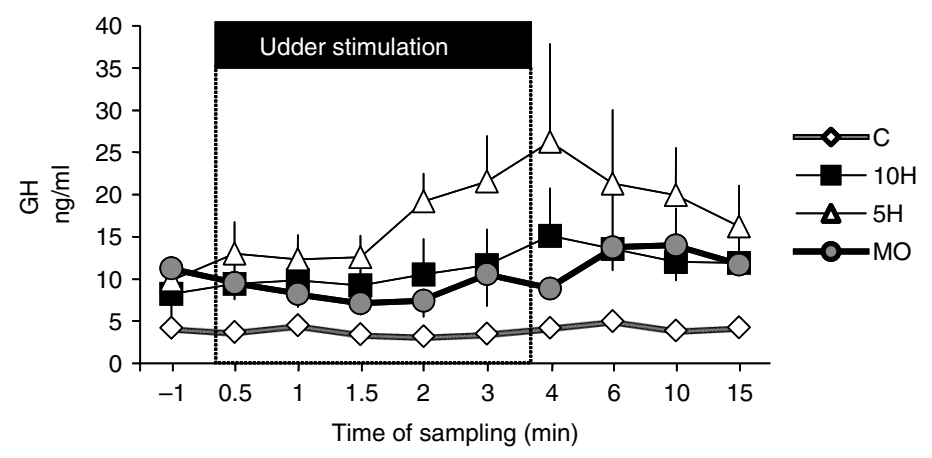

Figure 2 Plasma growth hormone concentrations $(\mathrm{GH}$, mean \pm s.e.) released in response to udder stimulation by 4 min of suckling $(\mathrm{C}, 10 \mathrm{H}$ and $5 \mathrm{H}$ groups) or $3 \mathrm{~min}$ of machine milking (MO group) of goats submitted to different durations of mother-young interaction (C $=$ free mother-kid interaction; $10 \mathrm{H}=10 \mathrm{~h}$ of mother-kid interaction per day and one machine milking; $5 \mathrm{H}=5 \mathrm{~h}$ of mother-kid interaction per day and one machine milking; $\mathrm{MO}=$ no mother-kid interaction and only one machine milking per day). Two-way ANOvA revealed a tendency for group and time of sampling effects $(P=0.07$ and $P=0.06)$.

synthesis by the udder is highly dependent on the local effect of previous udder evacuation (goats: Wilde and Knight (1990); cattle: Stelwagen and Knight (1997)) and is particularly pronounced when changing from once to twice daily milking, as this can lead to a 26 to $46 \%$ increase in milk yield (Mocqot and Guillimin, 1975; Papachristoforou et al., 1982; Wilde and Knight, 1990). In the present experiment nursing allowed a milk production equivalent to that obtained with twice daily milking, thus allowing kids to be reared without significant loss in milk collection. In addition, the absence of a difference in milk production at day 37 between mothers kept permanently with their kids (in which nursing occurs at about hourly intervals) (Lévy and Alexandre, 1985; Delgadillo et al., 1997; Hernández, 2001) and mothers where interactions were restricted to 10 or even $5 \mathrm{~h} /$ day, indicates that as little as $5 \mathrm{~h}$ of motheryoung interactions are sufficient to promote an adequate evacuation and udder stimulation for optimal milk synthesis and production.

Plasma PRL and GH concentrations during udder stimulation

There was a significant effect of restricting mother-young contact to $5 \mathrm{~h} /$ day on the pre-stimulation basal concentrations of PRL, while no clear differences were found between the response to suckling in mothers left in permanent contact with their young and the response to milking in females submitted to milking only. The results were similar for GH, except that mothers totally separated from their young (MO group) also showed higher basal concentrations than the control group. The higher basal concentrations of PRL and $\mathrm{GH}$ found in dams experiencing restricted contact with their kids, and more especially in the $5 \mathrm{~h}$ contact group, are consistent with the maintenance of milk production associated with the galactopoïetic effects of these hormones.

The presence of maternal behaviour does not appear to be in itself an important factor in facilitating the release of $\mathrm{PRL}$ and GH in the goat, since the hormonal responses to machine milking in goats totally separated from their kids were not significantly lower than those induced by nursing in goats kept in permanent contact with them. This appears to be at variance with results reported in cattle. For example, the PRL response was weaker in cows milked in the presence of their calf than when the young was absent (Gordon et al., 1979; Akers and Lefcourt, 1982 and 1984).

\section{Growth of the kids}

Restricting daily mother-young interactions to 5 or $10 \mathrm{~h}$ reduced kid growth by $20 \%$ to $33 \%$ compared with that of kids staying permanently with their non-milked dams. Such a reduction is not very surprising, since it was associated with one collection of milk through milking that reduced by about half the quantity of milk that the young could consume, compared with that available to kids of the control group. The situation was similar in the MO group, in which the quantity of milk consumed by the kids was limited to a similar extent by the reduced production that occurs with one milking per day, as this is 54 to $74 \%$ of that obtained by twice daily evacuation of the udder (Mocqot and Guillimin, 1975; Papachristoforou et al., 1982; Wilde and Knight, 1990). Our results are also in agreement with those previously reported in ewes and goats by Hadjipanayiotou and Louca (1976). On the other hand, other studies report a growth rate in lambs with restricted access to their dam similar to that found in lambs with permanent access to their mothers (Folch and Blasco, 1987; Mandiki et al., 1990). Nevertheless, the differences of management between experiments can probably account for these differences. In those latter studies, the period of mother-young contact was divided into two or more phases during the day, and no milking was performed. This allowed some time for milk synthesis and re-accumulation, and therefore the lambs consumed a major quantity of cisternal milk in each suckling session, thus obtaining growth rates similar to those of lambs that suckled freely. Similarly in cattle, the daily weight gain of calves is higher when some time of re-accumulation is allowed after milking before reuniting the calves with their dams (Pérez, 1992). 


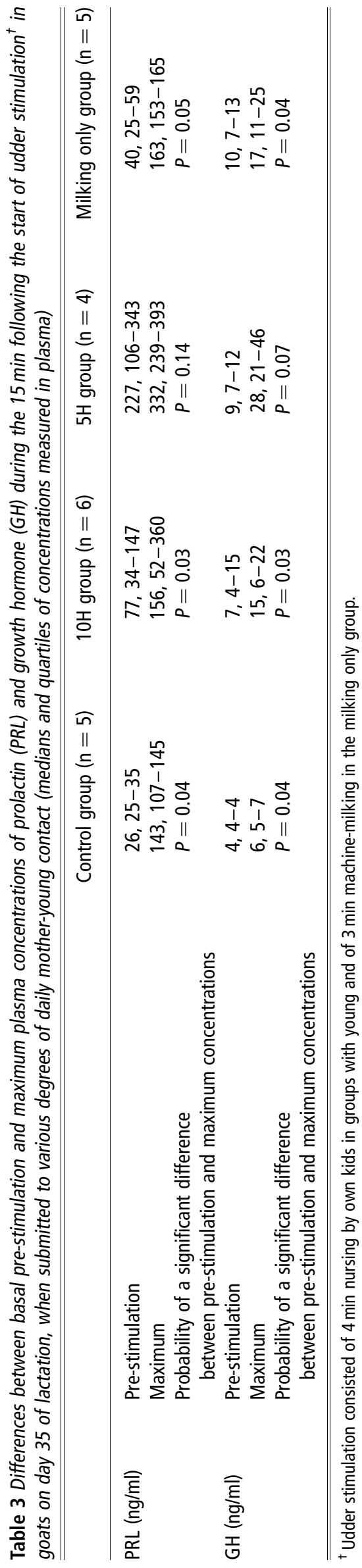

The most likely factor that allowed the kids of the three experimental groups to partially compensate for the reduction in milk availability is a difference in concentrate consumption. Kids reared with their dam can start ingesting concentrate at about 3 weeks of age (Lévy and Alexandre, 1985). The kids in the three groups in which machine milking was performed had ad libitum access to concentrate, whereas in the control group this access was limited to the time when mothers were fed. Therefore, it is likely that the kids of the three former groups began to ingest concentrate earlier and consumed significantly larger quantities of it than the controls, even though this parameter was not measured.

\section{General conclusion}

The results of the present study indicate that an early collection of milk can be made in nursing goats without a major effect on the growth of the kids. The reduced growth rate of the kids would largely be compensated by the milk collected through milking and by removing the need for artificial milk that would be necessary to feed the kids if there was complete mother-young separation. This management system appears potentially attractive not only for producers of kid meat, but also for dairy farmers that normally would perform one daily milking, as is often the case in developing countries. In addition, maintaining the mother-young relationship is likely to have positive consequences on the welfare of the mothers and their young. However, the present results were obtained in optimal breeding conditions, in that the dams were of a dairy type, provided with adequate feed and that the kids had access to concentrate and good quality forage. It would be important to investigate whether similar results would be obtained in more extensive conditions found in semi-arid climates, in goats with a lower milk potential and with reduced supplementary feeding.

\section{Acknowledgements}

The authors wish to thank M.Sc. Rosalba Soto and Facultad de Estudios Superiores Cuautitlán UNAM, for providing the animals. We are also grateful to Martha Segundo and Diego Rueda for the care of animals. This study was supported by PAPIIT-UNAM, Grant IN212796. H. Hernandez was supported by CONACyT scholarship for doctoral studies.

\section{References}

Akers RM and Lefcourt AM 1984. Effect of presence of the calf on milkinginduced release of prolactin and oxytocin during early lactation of dairy cows. Journal of Dairy Science 67, 115-122.

Akers RM and Lefcourt AM 1982. Milking and suckling-induced secretion of oxytocin and prolactin in parturient dairy cows. Hormones and Behavior 16, 87-93.

Alvarez FJ, Saucedo G, Arriaga A and Preston TR 1980. Effect on milk production and calf performance of milking crossbred European/Zebu cattle in the absence or presence of the calf and rearing their calves artificially. Tropical Animal Production 5, 25-37.

Bar-Peled U, Maltz E, Bruckental I, Folman Y, Kali Y, Gacitua H and Lehrer R 1995. Relationship between frequent milking or suckling in early lactation 
and milk production of high producing dairy cows. Journal of Dairy Science 78, 2726-2736.

Cepeda PR 1993. Crianza de cabritos. In Proceedings of the national seminary on production and commercialization in goats, Monterrey NL, Mexico, pp. 3136 Asociación de Zootecnistas y Técnicos Especialistas en Caprinocultura.

Coblentz BE 1974. Ecology, behavior and range relationships of the feral goat, Ph.D. thesis, University of Michigan.

Delgadillo JA, Poindron P, Krehbiel D, Duarte G and Rosales E 1997. Nursing, suckling and postpartum anoestrus of creole goats kidding in january in subtropical Mexico. Applied Animal Behavior Science 55, 91-101.

Food and Agriculture Organisation 1982. Anuario FAO de Producción, vol. 36, pp. 217-219

Ferrando $\mathrm{G}$ and Boza J 1990. Lactación de la cabra y los factores que la regulan. Annales de la Academia de Ciencias Veteterinarias de Andalucia Oriental 2, 46-77.

Folch J and Blasco I 1987. Influencia del tiempo de amamantamiento sobre el anoestro postparto de la oveja Aragonesa en primavera. Información Técnica Económica Agropecuaria 7, 340-342.

Folman Y, Volcani R and Eyal E 1966. Mother-offspring relationships in Awassi sheep. I. The effect of different suckling regimes and time of weaning on the lactation curve and milk yield in dairy flocks. Journal of Agricultural Science, Cambridge 67, 359-368.

Gordon T, Goodman H, Tucker A and Convey EM 1979. Presence of the calf affects secretion of prolactin in cows (40565). Proceedings of the Society for the Experimental Biology and Medicine 169, 421-424.

Grosvenor CE, Mena F and Whitworth NS 1979. The secretion rate of prolactin in the rat during suckling and its metabolic clearance rate after increasing intervals of nonsuckling. Endocrinology 104, 372-375.

Hadjipanayiotou M 1985. The effect of suckling type on the pre-and postweaning lactation performance of Damascus goats and the growth rate of the kids. Annales de Zootechnie 34, 489.

Hadjipanayiotou M and Louca A 1976. The effects of partial suckling on lactation performance of Chios sheep and Damascus goats and the growth rate of the lambs and kids. Journal of Agricultural Science, Cambridge 87, 15-20.

Hernández H 2001. Análisis de la conducta de amamantamiento en cabras y ovejas y sus relaciones con la fisiología materna. Ph.D. thesis, Universidad Nacional Autónoma de México.

Hoyos G, Saenz P and Salinas G 1991. Desarrollo de módulos caprinos en la Región Lagunera. Evaluación de módulos caprinos en la Comarca Lagunera, pp. 1-11. Instituto Nacional de Investigaciones Forestales Agrícolas y Pecuarias.

Kann G 1971. Dosage radioimmunologique de la prolactine plasmatique chez les ovins. Compte Rendu Hebdomadaire de l'Academie des Sciences 272, 2808-2811.

Knights M and Garcia GW 1997. The status and characteristics of the goat (Capra hircus) and its potential role as a significant milk producer in the tropics: a review. Small Ruminant Research 26, 203-215.

Lacroix MC, Devinoy E, Servely JL, Puissant C and Kann G 1996. Expression of the growth hormone gene in ovine placenta: detection and cellular localization of the protein. Endocrinology 137, 4886-4892.
Le Neindre P 1984. La relation mère-jeune chez les bovins. Influences de l'environnement social et de la race. Ph.D. thesis, Université de Rennes, France.

Lévy $\mathrm{F}$ and Alexandre G 1985. Le comportement alimentaire du cabri créole élevé en stabulation libre de la naissance au sevrage. Annales de Zootechnie 34, 181-192.

Lickliter RE 1984. Hiding behavior in domestic goat kids. Applied Animal Behavior Science 12, 245-251.

McDougall P 1975. The feral goats of Kielderhead Moor. Journal of Zoology $176,215-246$.

Mandiki SNM, Bister JL and Paquay R 1990. Effects of suckling mode on endocrine control of reproductive activity in Texel ewes lambing in July or November. Theriogenology 33, 397-413.

Mocqot JC and Guillimin P 1975. Effets de différentes fréquences de traite sur la production laitière des chèvres. Recherche Ovine et Caprine 11, 12531260.

Morag M, Raz A and Eyal E 1970. Mother-offspring relationships in Awassi sheep. IV. The effect of weaning at birth, or after 15 weeks, on lactational performance in the dairy ewe. Journal of Agricultural Science, Cambridge 75, 183-187.

National Research Council. 1981. Nutrient requirements of goats: Angora, dairy, and meat goats in temperate and tropical countries. National Academy Press, Washington.

Papachirtoforou C 1990. The effects of milking method and post-milking suckling on ewe milk production and lamb growth. Annales de Zootechnie 39, 1-8.

Papachristoforou C, Roushias A and Mavrogenis AP 1982. The effect of milking frequency on the milk production of Chios ewes and Damascus goats. Annales de Zootechnie 31, 37-48.

Perez O, Jimenez de Perez N, Poindron P, Le Neindre P and Ravault JP 1985. Relations mère-jeune et réponse prolactinique à la stimulation mammaire chez la vache: influences de la traite et de l'allaitement libre ou entravé. Reproduction, Nutrition, Development 25, 605-618.

Pérez P 1992. Efecto del amamantamiento y la presencia del macho en el reestablecimiento de la actividad reproductiva postparto en vacas Bos taurus $\times$ Bos indicus en un sistema de rejergueria. M.Sc. thesis, Colegio de Postgraduados, Chapingo México.

Peris S, Caja G, Such X, Casals R, Ferret A and Torre C 1997. Influence of rearing systems on milk composition and yield of Murciano-Granadina dairy goats. Journal of Dairy Science 80, 3249-3255.

Ricordeau G, Boccard R and Denamur R 1960. Mesure de la production laitière des brebis pendant la période d'allaitement. Annales de Zootechnie 9 , 97-120.

Rudge MS 1970. Mother and kid behaviour in feral goats (Capra hircus). Zeitschrift Tierpsychology 27, 687-692.

Stelwagen K and Knight $\mathrm{CH}$ 1997. Effect of unilateral once or twice daily milking of cows on milk yield and udder characteristics in early and late lactation. Journal of Dairy Research 64, 487-494.

Wilde CJ and Knight CH 1990. Milk yield and mammary function in goats during and after once-daily milking. Journal of Dairy Research 57, 441-447. 